direction on clinical investigations are apposite in this book.

(I) The doctor must himself understand their purpose.

(2) The enquiry must be explained to the patient, who must consent.

(3) Publications must be in a form acceptable to the uninformed doctor, i.e. the investigations, aim and behaviour must be unexceptionable.

Appendix 2 contains the code of medical ethics adopted by World Medical Association, 1949, and the duties of doctors in general, to the sick and to each other.

The bibliography is wide and useful.

Doctors should possess this unique volume of 192 pages, it is full of wise counsel and information; the reviewer found it difficult not to quote much more of it.

\section{DIFFUSE LESIONS OF THE STOMACH}

By I. J. WooD, M.D., F.R.C.P., F.R.A.C.P., and L. I. TAFT, M.B., B.S., B.Sc. Pp. viii + 86, with 35 illustrations. London: Edward Arnold Ltd. 1958. 24s.

Gastric biopsy is giving us more exact information about those diffuse changes in the mucosa which are obscured by post-mortem autolysis. Chronic inflammations and atrophies which at one time were doubtful histological entities can now be diagnosed with assurance and their progress followed. The technique is not without some dangers and it is not yet widely practiced. This book embodies the experience of one of the pioneer groups and gives useful data. There are three colour photomicrographs which are not so good and 25 black and white which are of better quality.

\section{THE BORDERLAND OF EMBRYOLOGY AND PATHOLOGY}

By Professor R. A. Willis, D.Sc., M.D., F.R.C.P. Pp. ix +627 +index, with 242 illustrations. London: Butterworth \& Co. Ltd. 1958. 90s.

A most valuable book by one of our leading pathologists who is also the greatest authority on teratology. His interest in embryology and comparative morphology in relation to pathology dates back to the very beginning of his career when he came under the influence of Keith and Nicholson. This book (the latest of a great sequence) is the happy product of continued labour during retirement enforced by ill-health, and this appreciation goes with our best wishes.

The treatment is comprehensive but, with so wide a field and so individual an approach, it is perhaps inevitable that some specialists will be a little disappointed.

The index is not complete but has the advantage of emphasizing important references. There is a chapter on suggested projects for research.

\section{DRUG TREATMENT OF DISEASE}

A new series of articles is now appearing in the $\frac{3}{\Phi}$ British Medical fournal on the drug treatment of $\stackrel{\AA}{\varrho}$ disease. The Editor of the British Medical Fournal $C$ writes of it: New drugs come from the laboratories $\vec{F}$ with bewildering speed, and any doctor may be $\stackrel{\mathcal{O}}{+}$ pardoned for feeling puzzled about when to pre-을 scribe a new vasoconstrictor called, for instance, $\frac{\overline{ }}{2}$ ' luvomine,' whose composition is given in a $\frac{\bar{c}}{\frac{1}{b}}$ chemical name that is in large part Greek letters $\mathbb{\mathscr { Q }}$ and Arabic numerals. His bewilderment increases 0 when he finds that half a dozen similar preparations $\$$ are on the market, each having a different 'side- $\overrightarrow{0}$ chain' attached somewhere and each varying to a $\overrightarrow{\vec{H}}$ greater or lesser extent in its effects. In order to $\vec{\omega}$ try to give some guidance on the pharmacology and $\frac{\Omega}{\circ}$ therapeutic uses of drugs, we have invited distin- 6 guished contributors to provide a series of signed 3 . articles which it is hoped will be helpful to the general physician and surgeon. The first is on the $\omega$ antihistamines, by Professor J. H. Burn, F.R.S.

\section{PRACTICAL CLINICAL BIOCHEMISTRY}

By Harold Varley. Second Edition. Pp. 635, $\vec{c}$ figs. 78. London: William Heinemann Medical Books. 42s.

The second edition of this excellent book, comin three years after the publication of the first, is ve o welcome. It has grown in size a little as severa. 6 new methods have been added-those for the determination of serum transaminases and of $5-\frac{1}{5}$ hydroxy indoles will be particularly useful. The chapter on hormones has been largely rewritten and now occupies 43 pages; it includes a fluori- $\frac{Q}{\triangleright}$ metric method for urinary catecholamines. This is $\unrhd$ a practical and reliable textbook which is clearly $\overrightarrow{\vec{O}}$ written and well set out; the paragraphs, which give $\frac{3}{3}$ some indication of the relative merits of some of the different methods, have been found to be valuable and those on their interpretation both sensible and authoritative.

\section{CARE OF THE PREMATURE INFANT}

By E. C. LundeEn, R.N., and R. H. Kunstadter, 웅 M.D., F.A.C.P., F.A.A.P. Pp. xv +367 , illustrated. London: Pitman Medical Publishing Co.Ltd. 1958. 6os.

This book was written at the request of the of nurses of the Michael Reese Hospital, Chicago, $N$ and describes the work of their premature station. N The book is very detailed and reflects the unwel- $\sigma$ come tendency of some nurses, more particularly on the other side of the Atlantic, to become little doctors. Although there is much to praise and $\stackrel{D}{\rightarrow}$ little to quarrel with in the techniques described, a much shorter, simpler and cheaper book would serve a British nurse admirably. 